THE FUTURE OF MONEY 

Eswar S. Prasad

\title{
The Future of Money
}

\author{
How the Digital Revolution \\ Is Transforming Currencies \\ and Finance
}

THE BELKNAP PRESS OF

HARVARD UNIVERSITY PRESS

Cambridge, Massachusetts, and London, England 2021 
Copyright (C) 2021 by the President and Fellows of Harvard College All rights reserved

Printed in the United States of America

First printing

Many of the designations used by manufacturers and sellers to distinguish their products are claimed as trademarks. Where those designations appear in this book and Harvard University Press was aware of a trademark claim, those designations have been formatted in initial capital letters.

Cover design and illustration: Oliver Munday and Paul Spella

9780674270084 (EPUB)

9780674270091 (PDF)

The Library of Congress has cataloged the printed edition as follows:

Names: Prasad, Eswar, author.

Title: The future of money : how the digital revolution is transforming currencies and finance / Eswar S. Prasad.

Description: Cambridge, Massachusetts : The Belknap Press of Harvard

University Press, 2021. | Includes bibliographical references and index.

Identifiers: LCCN 2021008025 | ISBN 9780674258440 (cloth)

Subjects: LCSH: Digital currency. | Banks and banking, Central. |

International finance.

Classification: LCC HG1710.3 .P73 2021 | DDC 332.4-dc23

LC record available at https://lccn.loc.gov/2021008025 


\section{To Basia}

My best friend and partner in everything

Zawsze i na zarwsze 
